\title{
UJI PREDIKSI UMUR KEANDALAN OPERASI RADIAL BALL BEARING PADA MOTOR DIESEL SINGLE CYLINDER DENGAN PENDEKATAN AMBANG BATAS KEAUSAN
}

(Studi Eksperimental Pada Motor Diesel 15 HP, Torsi Maksimum 880 kgf-cm, putaran normal 1700 RPM/maks. 2145 RPM)

\author{
M Rusdy Hatuwe ${ }^{1}$, Yuhani Djaja ${ }^{2}$ \\ Program Studi Teknik Mesin, Universitas Pembangunan Nasional "Veteran” Jakarta,Indonesia ${ }^{12}$ \\ email: mohrushhat@rocketmail.com
}

\begin{abstract}
Factually where the bearingss are not functioning properly makes the performance of the entire system will decrease or can not work properly. In this study, the wear test data that will be used is the data for the operating hours of 100 hours, 200 hours, 300 hours, 400 hours and 500 hours and the first converted into a linear function to obtain a threshold of wear of each specimen. In accordance with the objectives to be achieved in this study was to determine the relationship between the limits hours of operation and wear limit set maximum ball bearings manufacturer. The data used in this study is through the mechanism of experimental tests on Diesel engines Yanmar 15 HP, 1700 RPM using 3 specimens to be validated. Furthermore, these data will be generated from a particular distribution which will provide an overview wear limit as a function of operating hours.
\end{abstract}

\section{PENDAHULUAN}

\section{LATAR BELAKANG}

Bantalan yang menjadi obyek penelitian disini adalah bantalan ball bearing pada motor diesel $15 \mathrm{hp}$ single engine yang mengalami kegagalan dan berimplikasi langsung pada keruskan komponen lainnya. Bantalan ini merupakan bantalan jenis radial yang mana pada tumpuan lainnya merpakan bantalan roll silinder yang mana secara visual dapat dikatakan masih dalam kondisi baik kecuali kerusakan kecil akibat kegagalan pasangannya radial ball baring.

Konsekuensi yang terjadi akibat kegagalan maka suatu komponen harus duganti, Anggapan bahwa penggantian (Replacement) suatu komponen dilakukan ketika mengalami kegagalan (failure replacement) belum tentu lebih menguntungkan dibandingkan dengan penggantian sebelum terjadi kegagalan / cegah ganti (preventive replacement) . Penggantian yang dilaksanakan secara terjadwal bila komponen tersebut belum mengalami deteriorasi (deterioration) yang berarti atau penggantian yang disebabkan atas penggantian komponen lannya maka diperlukan metode preventive replacement (penggantian untuk pencegahan kegagalan cegah ganti) pada interval waktu tertentu. Persoalan yang muncul adalah menentukan keseimbangan antara kebutuhan operasi dan pencegahan kegagalan yang berujung pada terhentinya operasi itu sendiri (unplaned downtime), sehingga menuntut penerapaqn model pemeliharaan yang lebih mengedepankan optimasi penggunaan peralatan ketimbang biaya yang semestinya dikeluarkan yaitu, kebijakan yang difokuskan pada meminimalkan total downtime persatuan waktu (maximize availibility) sehingga prediksi umur operasi suatu komponen sebagai dasar penggantian suatu komponen.

\section{TINJAUAN PUSTAKA KEANDALAN DAN KEGAGALAN}

Keandalan dapat didefinisikan suatu kemampuan sebuah alat untuk melaksanakan suatu fungsi yang diperlukan tanpa kegagalan dalam keadaan yang ditentukan untuk jangka waktu yang ditentukan . Kegagalan dapat terjadi pada awal pemakaian yang disebabkan karena kesalahan disain, produksi dan instalasi atau pada masa pakainya yang terjadi secara acak atau karena umurnya, maka menjadi usang atau aus dan lelah. Variable yang terpenting berkaitan dengan keandalan adalah waktu, terutama yang berhubungan dengan laju kerusakan (failure rate) yang dapat menjelaskan mengenai fenomena keandalan suatu sistem.

\section{KEAUSAN \\ DAN \\ KEGAGALAN BANTALAN GELINDING}

Pada bantalan gelinding terjadi gesekan gelinding antara bagian yang berputar dengan yang diam melalui elemen gelinding seperti 
bola (peluru), rol atau rol jarum atau rol bulat. Bantalan gelinding lebih cocok untuk beban kecil. Putaran pada bantalan gelinding dibatasi oleh gaya sentrifugal yang timbul pada elemen gelinding tersebut. Apabila ditinjau dari segi biaya, bantalan gelinding lebih mahal dari bantalan luncur. Kelebihannya adalah Keausan dan panas yang ditimbulkan berkurang, gesekan yang terjadi relatif konstan, pemakaian pelumas minimum, ukuran lebarnya kecil, mudah penggantiannya dan ukurannya sudah distandarisasikan sehingga mudah mendapatkan dimana saja. Sementara kekurangannya adalah untuk beban kejut (getaran karena ketidakseimbangan komponen mesin) bearing lebih cepat rusak, lebih sensitive terhadap debu dan kelembaban.

Pada pelumasan gemuk (lebih kental) maka gesekan putaran bebas lebih besar daripada pelumasan oli (sampai 2,5 kali), tetapi dengan peningkatan beban dan pemanasan yang disumbangkan oleh gesekan luncur lebih rendah, sehingga Momen gesek atau gesekan putaran permukaan meningkat. Jumlah putaran mempengaruhi angka gesekan sesuai dengan gambar 1. dengan bentuk konstruksi bantalan memegang peranan sangat penting. Pada beban bantalan yang rendah maka kerugiannya tidak tergantung pada beban (kerja gilingan dari bahan pelumas, kerugian dari pengarahan sarangan); disini adalah sangat tergantung pada jumlah putaran dan bersifat hampir linier. Pada umumnya ditunjukkan oleh bantalan gelinding suatu sifat yang mirip bantalan luncur.

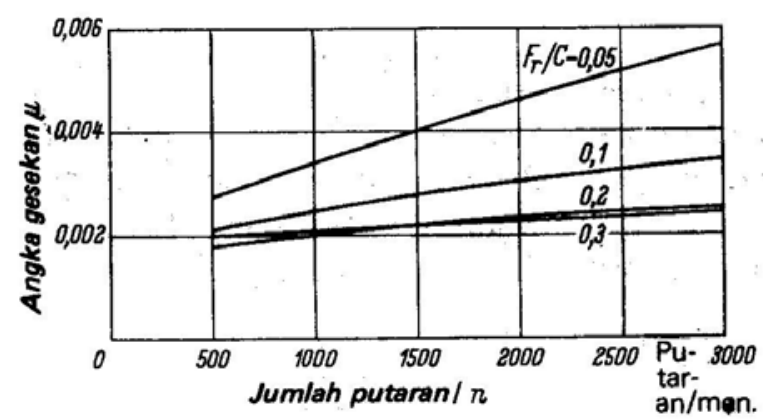

Gambar 1. Angka gesekan suatu bantalan peluru rol 6312 dalam ketergantungannya terhadap jumlah putaran dan bebannya menurut Eschmann, $\mathrm{F}_{\mathrm{r}}=$ beban radial dan $\mathrm{C}=$ Basic dynamic load rating [G.

Niemann, hal. 270].

Sedangkan bagian yang hilang dari permukaan yang saling bergesekan untuk macam-macam material seperti terlihat pada gambar 2.

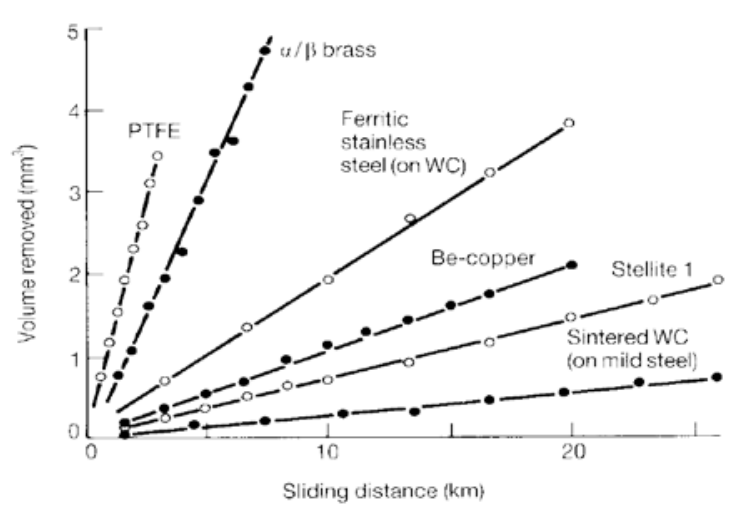

Gambar 2. Keausan, hasil pengujian volume pena yang hilang dari berbagai macam material akibat gesekan sepanjang jarak tempuh gesekan yang terjadi tanpa pelumasan [Introduction

Surfaces to Wear Interfaces, and their Applications II, hal. 8]

\section{UMUR BALL BEARING}

Umur efektif (rating life) dari sekumpulan bantalan bola didefinisikan sebagai jumlah putaran (atau jam pada kecepatan konstan) dimana $90 \quad \%$ dari sekumpulan bantalan akan mencapai atau melampaui kondisi sebelum terjadi kegagalan. Istilah umur minimum (minimum life) umur $\mathrm{L}_{10}$ dan umur $\mathrm{B}_{10}$ juga digunakan sebagai sinonim dari umur efektif. Sedangkan umur median (median life) adalah persen kelima puluh dari sekumpulan bantalan. Istilah umur rata-rata (average life) digunakan sebagai sinonim dari umur median. Pada sejumlah bantalan yang diuji umur median antara 4-5 kali dari $\mathrm{L}_{10}$. Umur bantalan sesuai katalog bantalan PYH dihitung dengan rumus 2

$$
L_{10 h}=\left(\frac{16667}{n}\right)\left(\frac{C_{r}}{p}\right)^{3}
$$

Dimana: $\mathrm{L}_{\mathrm{h} 10}=$ Basic rating life $(\mathrm{Jam})$, = Basic dynamic load rating $(\mathrm{N}), \mathrm{n}=$ R.P.M. (revolutions per minute), $\quad \mathrm{L}_{10 \mathrm{~h}}=$ Basic rating life in operating hours, $\mathrm{P}=$ Equivalent load $(\mathrm{N})$

\section{BASIC DINAMIC LOAD RATING C}

Pengujian yang telah dilakukan oleh perusahaan - perusahaan pembuat bantalan berdasarkan teori yang telah dikembangkan , menunjukkan bahwa fatique life atau umur bantalan L berbanding terbalik dengan pangkat tiga bebannya untuk bantalan bola , dan pangkat 10/3 untuk bantalan rol. Bantalan Bola ; L = $(\mathrm{Cr} / \mathrm{P})^{3}$ dan Bantalan Rol ; $\mathrm{L}=(\mathrm{Cr} / \mathrm{P})^{10 / 3}$. Dimana $\mathrm{L}$ adalah umur bantalan dalam jutaan 
putaran , $\mathrm{P}$ adalah beban konstan yang bekeja (beban kerja pada elemen berputar akan menyebabkan beban dinamik) dan $\mathrm{C}$ adalah basic dynamic load rating C. Load Dinamic Load Rating C didefinisikan sebagai beban yang akan memberikan umur 1 juta putaran pada cincin dalam. Parameter ini biasanya sudah ditentukan dalam katalog yang dibuat oleh perusahaan pembuat bantalan.

\section{BEBAN EKIVALEN}

Suatu beban yang besarnya sedemikian rupa hingga memberikan umur yang sama dengan umur yang diberikan oleh beban dan kondisi putaran sebenarnya disebut beban ekivalen dinamis.

Jika suatu deformasi permanen ekivalen dengan deformasi permanen ekivalen dengan deformasi permanen maksimum yang terjadi karena kondisi beban statis yang sebenarnya pada bagian dimana elemen gelinding membuat kontak dengan cincin pada tegangan maksimum, maka beban yang menimbulkan deformasi tersebut dinamakan beban ekivalen statis. Beban radial dinamik equivalen yang merupakan kombinasi dari beban radial dan beban aksial.

\section{PEMILIHAN BANTALAN}

Pemilhan bantalan mengacu pada SKF standard sesuai dengan bantalan yang digunakan pada system yang diteliti, yaitu bantalan kering radial ball bearing. Menurut standar SKF (Svenska Kullager Fabrike), ukuran bantalan yang diperlukan bagi bantalan yang berputar dapat ditentukan berdasarkan harga basic dynamic load rating (C). Agar pemilihan sesuai dengan standar bantalan maka harga $\mathrm{C}$ harus memiliki nilai yang lebih besar atau sama dengan harga yang diperlukan.

Namun, untuk beban statis yang menggunakan peringkat $\mathrm{C}_{0}$ maka dasar yang harus digunakan adalah jika bantalan akan dioperasikan pada putaran lambat dibawah 10 rpm, gerakan osilasi lambat, beban tetap dalam waktu yang lama, umumnya digunakan untuk suhu ekstrim yaitu kode bantalan dengan akhiran VA201, VA208 dan VA228.

Standar bantalan harus memiliki nilai Co yang lebih besar atau sama dengan yang diperlukan, harga $\mathrm{C}$ dan Co untuk bantalan bola alur dalam (deep groove ball bearings) dan Y.
Perhitungan berdasarkan Dynamic load rating,

$$
C_{r e q}=\frac{S_{r e q} P}{f_{T}} \text {. }
$$

Harga P ditentukan sesuai standar bantalan dimana $\mathrm{P}$ dipilih sama dengan

$$
\mathrm{F}_{\mathrm{r}}\left(\mathrm{P}=\mathrm{F}_{\mathrm{r}}\right) \text { jika } \mathrm{P}<\mathrm{F}_{\mathrm{r}} \text {. }
$$

Perhitungan berdasarkan Static load rating,

$$
C_{\text {oreq }}=\frac{2 P_{0}}{f_{T}}
$$

Harga $\mathrm{P}_{\mathrm{o}}$ ditentukan sesuai standar bantalan dimana $\mathrm{P}_{\mathrm{o}}$ dipilih sama dengan $\mathrm{F}_{\mathrm{r}}$ $\left(\mathrm{P}_{0}=\mathrm{F}_{\mathrm{r}}\right)$ jika $\mathrm{P}_{\mathrm{o}}<\mathrm{F}_{\mathrm{r}}$. Untuk deep groove ball bearing, $\mathrm{F}_{\mathrm{a}}$ tidak boleh lebih dari $0.15 \mathrm{C}_{0}$. Dimana, $\mathrm{C}_{\mathrm{req}}=$ Dynamic load rating yang diperlukan $(\mathrm{kN}), \mathrm{C}_{\mathrm{O} \text { req }}=$ Static load rating yang diperlukan $(\mathrm{kN}), \mathrm{F}_{\mathrm{a}}=$ Gaya aksial $(\mathrm{kN}), \mathrm{F}_{\mathrm{r}}=$ Gaya radial $(\mathrm{kN}), \mathrm{P}=$ Beban dinamis ekivalen $(\mathrm{kN}), \mathrm{P}_{\mathrm{o}}=$ Beban statis ekivalen $(\mathrm{kN}), \mathrm{S}_{\text {req }}=$ Faktor keamanan beban dinamis (tabel 2.), $\mathrm{f}_{\mathrm{T}}$ =faktor temperature (tabel 3)

Tabel 2 Faktor keamanan beban dinamis

\begin{tabular}{|l|l|}
\hline $\begin{array}{l}\text { Guldeline values for dynamic load } \\
\text { safety fector } S_{\text {Reg }} \text { application }\end{array}$ & 3 \\
\hline $\begin{array}{l}\text { Machines used for short period or } \\
\text { intermittenty: } \\
\text { colling beds guide rollers }\end{array}$ & \\
$\begin{array}{l}\text { Machines used for short period or } \\
\text { intermittenty where high operational } \\
\text { reliabillity is required : cranes of } \\
\text { metals aflications }\end{array}$ & 5 \\
$\begin{array}{l}\text { Machines in use 8 hours per day } \\
\text { and fully utilized: } \\
\text { Conveyor belt hardening and ann elling } \\
\text { ovens }\end{array}$ & 10 \\
$\begin{array}{l}\text { Machines and use } 24 \text { hours per day } \\
\text { Conveyer system equipment in }\end{array}$ & \\
continous csting mills & 12 \\
\hline
\end{tabular}

Tabel 3. Faktor temperatur operasi

\begin{tabular}{|c|c|c|}
\hline${ }^{\circ} \mathrm{C}$ & ${ }^{{ }^{\mathrm{F}}}$ & $\mathrm{f}_{\mathrm{T}}$ \\
\hline$=150$ & $=300$ & 1 \\
200 & 390 & 0,9 \\
250 & 480 & 0,75 \\
300 & 570 & 0,6 \\
350 & 660 & 0,45 \\
\hline
\end{tabular}

Khusus untuk bantalan lumas kering (Dry lubricated bearings) harus tetap dipertahankan kering dengan sedikit dilumasi minyak tanpa pengawet (minyak pelumas sifat anticrossion). 
Oleh karena itu bantalan harus digunakan dalam lingkungan kering atau pengaturan penyegelan yang tepat untuk menjaga bantalan tetap kering.

\section{BATAS PUTARAN (SPEED LIMITS)}

Batas putaran untuk varian SKF DryLube bearings dapat dihitung berdasarkan tabel 4 . dimana diagram pada gambar 3. merupakan harga estimasinya. Jika kelonggaran (clearance) lebih besar dari C3, maka batas putaran harus diturunkan sesuai dengan Diagram pada gambar 3 dan gambar 4 . Mengacu pada batas putaran maka varian bantalan dapat ditentukan berdarkan pada gambar 3 .

Tabel 4. Karakteristik bantalan kering standar SKF

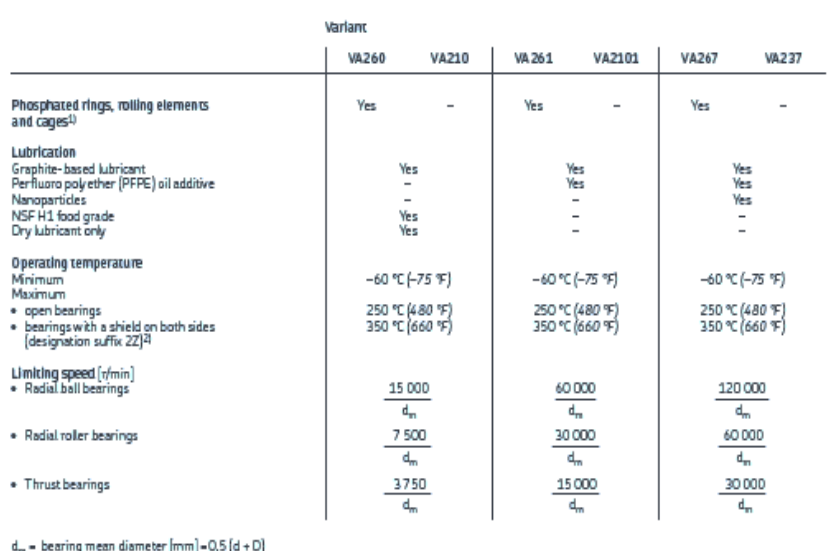

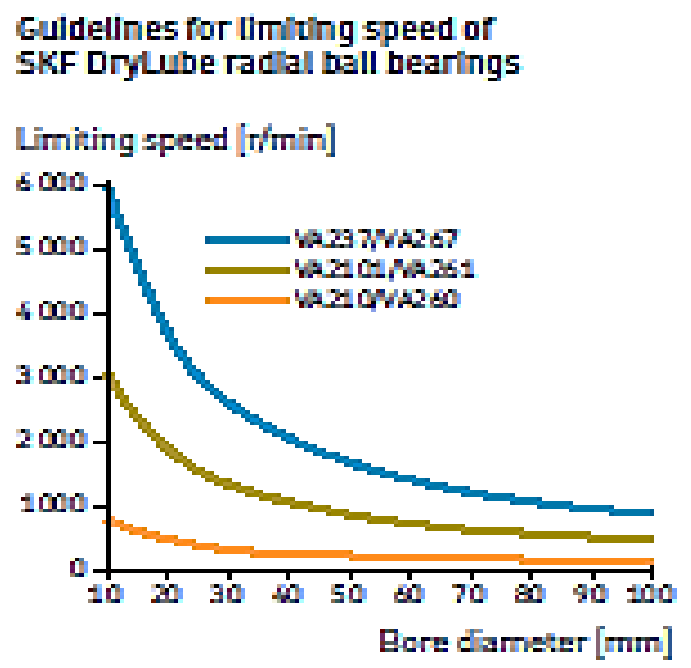

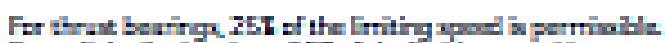

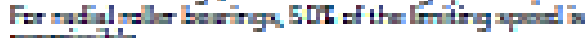
purimite

Gambar 3. Perkiraan putaran

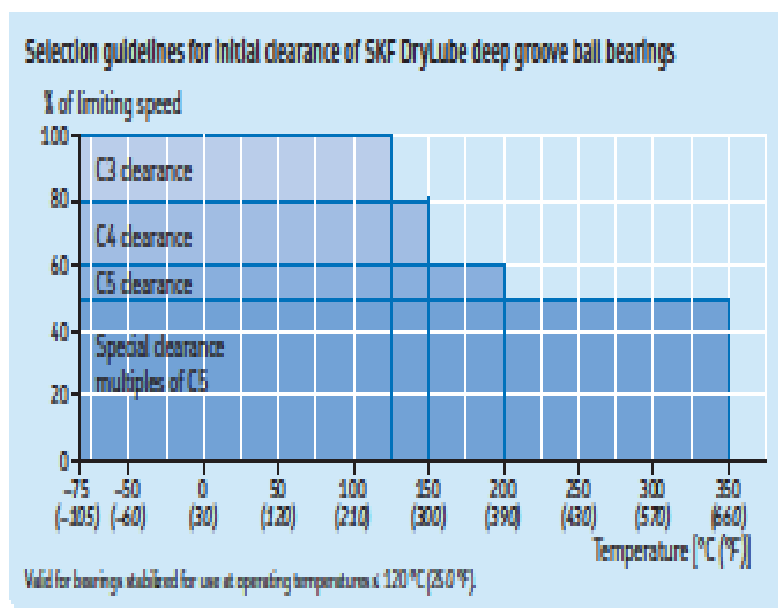

Gambar 4. Diagram koreksi putaran

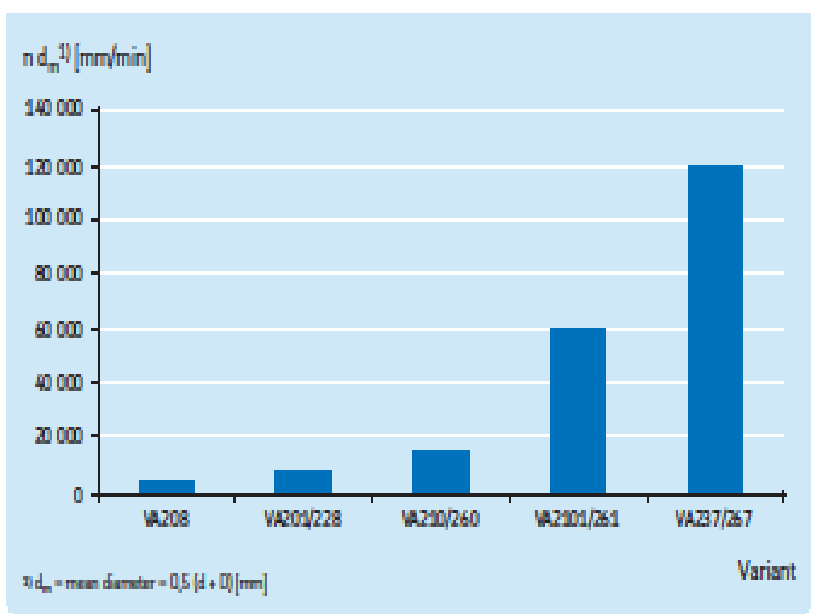

Gambar 5. Hubungan antara varian bantalan dan batas putaran operasi

Tabel 5. Toleransi Diameter dalam dan luar ball bearing

\begin{tabular}{|c|c|c|c|c|c|}
\hline \multicolumn{6}{|c|}{ Tolerances of dry lubricated Y-bearings } \\
\hline \multicolumn{2}{|c|}{$\begin{array}{l}\text { Nominal } \\
\text { dlameter } \\
d, D \\
\text { over ind. }\end{array}$} & \multicolumn{2}{|c|}{$\begin{array}{l}\text { Bore } \\
\text { dameter" } \\
\text { Deviation }\end{array}$} & \multicolumn{2}{|c|}{$\begin{array}{l}\text { Outside } \\
\text { dlameter } \\
\text { Devistion }\end{array}$} \\
\hline $\mathrm{mm}$ & & $\boldsymbol{\mu} \mathbf{m}$ & & $\mu \mathrm{m}$ & \\
\hline $\begin{array}{l}18 \\
30\end{array}$ & $\begin{array}{l}30 \\
50\end{array}$ & $\begin{array}{r}+18 \\
+21\end{array}$ & $\begin{array}{l}0 \\
0\end{array}$ & $\overline{0}$ & $\overline{-10}$ \\
\hline $\begin{array}{l}50 \\
80\end{array}$ & $\begin{array}{l}80 \\
120\end{array}$ & $\begin{array}{l}+24 \\
+28\end{array}$ & $\begin{array}{l}0 \\
0\end{array}$ & $\begin{array}{l}0 \\
0\end{array}$ & $\begin{array}{l}-10 \\
-15\end{array}$ \\
\hline
\end{tabular}


Tabel 6. Kelonggaran radial

\begin{tabular}{|c|c|c|c|c|c|}
\hline $\begin{array}{l}\text { Bore } \\
\text { d }\end{array}$ & Ilameter & $\begin{array}{l}\text { Rad } \\
\text { Daef } \\
\text { ball: }\end{array}$ & $\begin{array}{l}\text { micert } \\
\text { mone } \\
\text { grimges }\end{array}$ & $\begin{array}{l}\text { clear } \\
\text { Y-be }\end{array}$ & $\begin{array}{l}\text { noe } \\
\text { ings }\end{array}$ \\
\hline Drer & ind. & min & max & min & max: \\
\hline \multicolumn{2}{|l|}{ mim } & \multicolumn{4}{|l|}{$\mu \pi$} \\
\hline & 10 & 40 & 136 & - & - \\
\hline 10 & 19 & 50 & 1ED & - & - \\
\hline 10 & 24 & $5 \mathrm{t}$ & 172 & $5 \mathrm{t}$ & 96 \\
\hline 24 & 30 & 60 & 192 & 60 & 105 \\
\hline 30 & 40 & BD & 276 & BD & $12 B$ \\
\hline 40 & 50 & 90 & 272 & 90 & 145 \\
\hline 50 & 65 & 110 & 340 & 110 & 180 \\
\hline 65 & BD & 170 & 40] & - & - \\
\hline 80 & 120 & 150 & $4 E 0$ & - & - \\
\hline
\end{tabular}

\section{METODE PENELITIAN}

Sesuai dengan tujuan yang ingin dicapai pada penelitian ini adalah untuk menentukan hubungan antara batas jam operasi dan batas keausan ball bearing maksimum yang ditetapkan pembuatnya. Data yang digunakan dalam penelitian ini yaitu melalui mekanisme pengujian eksperimen pada Diesel engine Yanmar 15 HP 1700 RPM dengan menggunakan 3 spesimen yang telah divalidasi dilaboratorium Teknik Mesin UPN "Veteran" Jakarta. Daari hasil tersebut diperoleh suatu distribusi tertentu yang memberikan gambaran distribusi laju keausan. Selanjutnya dapat diketahui fungsi densitas probabilitas (fungsi kepadatan) atau fungsi distribusi probabilitas sehingga dapat ditetapkan tingkat keandalan ball bearing sesuai dengan karakteristik operasinya. Menyangkut tahapan penelitian ini secara rinci yaitu seperti pada gambar tahapan penelitian. Dalam penelitian ini data uji keausan dipergunakan adalah data 100 jam, 200 jam, 300 jam, 400 jam dan 500 jam dan dikonversi terlebih dahulu ke dalam fungsi linier untuk mendapatkan ambang batas keausan masing-masing spesimen. Untuk mendapatkan jam operasi yang andal walaupun hanya menggunakan tiga spesimen, maka selanjutnya ketiga data ambang batas tersebut diproses dengan pendekatan distribusi Weibull.

Untuk mencapai tujuan penelitian, kegiatan penelitian sebagai berikut :

a. Tahap awal

1. Persiapan spesimen.

2. Data spesifikasi ball bearing.

3. Data batas operasi ball bearing

4. Persiapan Instrumen/alat uji

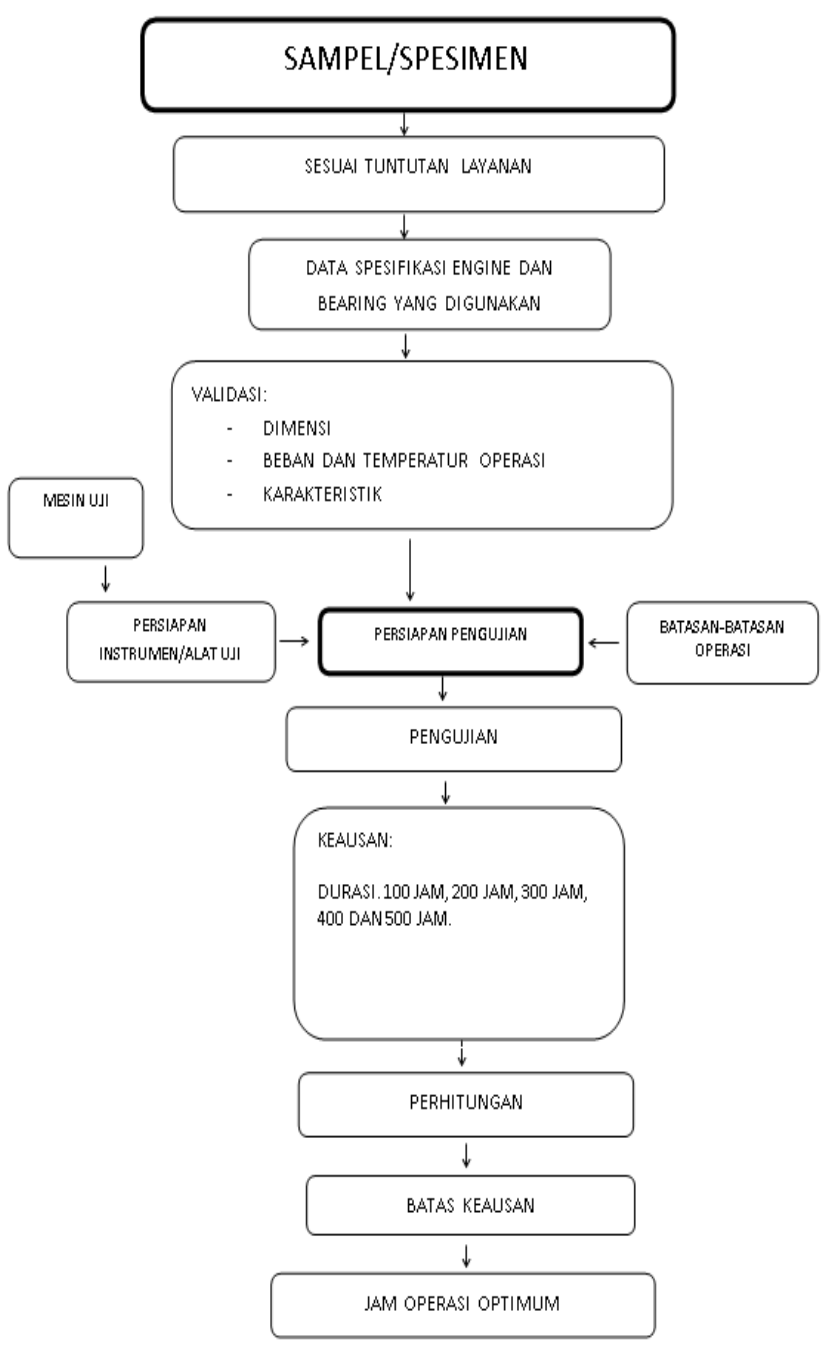

Gambar 3. Desain Eksperimen

\section{BATASAN OPERASI.}

Data batasan operasi yang dimaksudkan pada penelitian ini adalah yang terhubunan langsung dengan parameter spesimen bearing sebagaimana terlihat pada tabel 3. 1 .

Tabel 3.1. Parameter Instrumen uji

\begin{tabular}{|c|c|c|c|c|c|}
\hline \multicolumn{4}{|c|}{ Diesel engine } & \multicolumn{2}{|c|}{ Generator Mesin las } \\
\hline $\begin{array}{l}\mathrm{DS} / \mathrm{d}, \\
\mathrm{HP}\end{array}$ & $\begin{array}{l}\text { Putaren } \\
\text { stationet, } \\
\text { RPM }\end{array}$ & $\begin{array}{c}\text { Tosi } \\
\text { msismum, } \\
\text { igfom }\end{array}$ & $\begin{array}{l}\text { Tempestu } \\
\text { opers, }\end{array}$ & $\begin{array}{c}\text { De/s } \\
\text { output } \\
\text { KW }\end{array}$ & $\begin{array}{c}\text { opersi } \\
\text { nermitert } \\
\text { jamingn }\end{array}$ \\
\hline 19 & 1700 & 880 & $80-100$ & 9,75 & 8 \\
\hline
\end{tabular}

\section{PERSIAPAN SPESIMEN :}

Spesimen Ball bearing yang dipergunakan dalam penelitian ini akan disesuaikan dengan kondisi dan batasan operasi sesuai dengan rumus 2. dan secara umum mengacu pada diameter dudukan crankshaft dan diameter 
lubang case engine seperti pada table 3.2 berikut ini.

Tabel 3.2. Atribut dan nilai SKF Radial ball bearing

\begin{tabular}{|l|l|}
\hline \multicolumn{1}{|c|}{ Atributtes } & \multicolumn{1}{c|}{ Values } \\
\hline Bore Dia (d) & $45 \mathrm{~mm}$ \\
\hline Outer Dia (D) & $100 \mathrm{~mm}$ \\
\hline Width (B) & $25 \mathrm{~mm}$ \\
\hline Ball Qty & 8 \\
\hline Ball Dia (Dw) & $17.463 \mathrm{~mm}$ \\
\hline Contact angel & 0 degree \\
\hline
\end{tabular}

\section{PERSIAPAN INSTRUMEN :}

Untuk keperluan pengujian dan pengambilan data yaitu menggunakan mesin uji keausan yang ada di lab FT-UPNVJ yang terdiri dari :

Unit mesin Yanmar-Diesel Generetor 15 HP 1700 RPM yang digunakan untuk menggerakkan generator mesin las dengan maximum rated output $5.75 \mathrm{~kW}$

\section{PEMBAHASAN}

\section{BEBAN EKIVALEN BANTALAN}

Beban bantalan ditentukan berdasarkan beban yang diteruskan dari poros engkol yang dihasilkan oleh tekanan pembakaran didalam ruang bakar engine sesuai dengan spesifikasi motor diesel yang digunakan seperti pada tabel 3.3.

Parameter beban bantalan

\begin{tabular}{|c|l|l|l|}
\hline Simbol & Deskripsi & \multicolumn{2}{|c|}{ Besaran unit } \\
\hline $\mathrm{D}_{\mathrm{s}}$ & $\begin{array}{l}\text { Diameter dalam } \\
\text { silinder engine }\end{array}$ & $7.5 \mathrm{~cm}$ & $75 \mathrm{~mm}$ \\
\hline $\mathrm{p}$ & $\begin{array}{l}\text { Tekanan } \\
\text { pembakaran }\end{array}$ & $\begin{array}{l}15.25 \\
\mathrm{kgf} / \mathrm{cm}^{2}\end{array}$ & $\begin{array}{l}1.5 \\
\mathrm{~N} / \mathrm{mm}^{2}\end{array}$ \\
\hline $\mathrm{W}$ & Berat Crank shaft & $4 \mathrm{kgf}$ & $39.23 \mathrm{~N}$ \\
\hline $\mathrm{F}$ & $\begin{array}{l}\text { Gaya dorong } \\
\text { pembakaran, } \\
\mathrm{F}=(\pi / 4) D_{\mathrm{s}}^{2} \mathrm{p}\end{array}$ & $675.7 \mathrm{~kg}$ & $6628.86 \mathrm{~N}$ \\
\hline $\mathrm{W}_{1}$ & Berat Fly wheel & $14.5 \mathrm{kgf}$ & $142.2 \mathrm{~N}$ \\
\hline $\mathrm{W}_{2}$ & Berat Pulley & $3.5 \mathrm{kgf}$ & $34.32 \mathrm{~N}$ \\
\hline $\mathrm{L}_{1}$ & $\begin{array}{l}\text { Jarak Radial roll } \\
\text { bearing dengan } \\
\text { crank center }\end{array}$ & $5.1 \mathrm{~cm}$ & $51 \mathrm{~mm}$ \\
\hline $\mathrm{L}_{2}$ & Jarak antar bearig & $10.8 \mathrm{~cm}$ & $108 \mathrm{~mm}$ \\
\hline $\mathrm{L}_{3}$ & $\begin{array}{l}\text { Jarak Radial roll } \\
\text { bearing dengan } \\
\text { fly wheel }\end{array}$ & $18 \mathrm{~cm}$ & $180 \mathrm{~mm}$ \\
\hline $\mathrm{L}_{4}$ & $\begin{array}{l}\text { Jarak Radial roll } \\
\text { bearing dengan } \\
\text { pulley }\end{array}$ & $24.5 \mathrm{~cm}$ & $245 \mathrm{~mm}$ \\
\hline
\end{tabular}

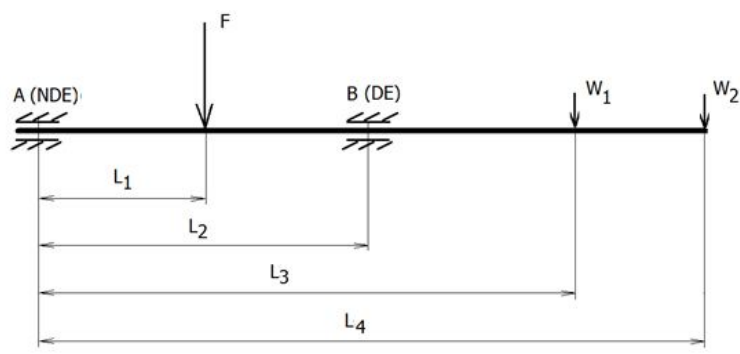

Gambar 3.1. Diagram Pembebanan pada Crank shaft

Reaksi di B=Beban vertical murni yang diterima oleh Radial ball bearing sebesar:

$$
\left.\mathrm{F}_{\mathrm{r}}=\left(\mathrm{FL}_{1}+\mathrm{W}_{1} \mathrm{~L}_{3}+\mathrm{W}_{2} \mathrm{~L}_{4}\right)\right) / \mathrm{L}_{2}
$$

Dimensi specimen

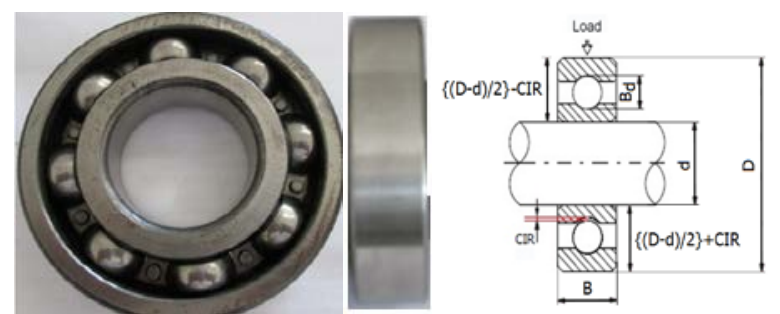

\begin{tabular}{|c|c|c|c|c|c|}
\hline \multirow[b]{2}{*}{ No } & \multirow{2}{*}{$\begin{array}{l}\text { d, mm } \\
\text { Sebelum/ } \\
\text { sesudah }\end{array}$} & \multirow{2}{*}{$\begin{array}{l}\text { D, mm } \\
\text { Sebelum/ } \\
\text { sesudah }\end{array}$} & \multirow{2}{*}{$\begin{array}{l}\text { B, mm } \\
\text { Sebelum } \\
\text { / } \\
\text { sesudah }\end{array}$} & \multicolumn{2}{|c|}{$\begin{array}{c}\text { CIR, } \mu \mathrm{m} \\
\text { (minimum) }\end{array}$} \\
\hline & & & & $\begin{array}{l}\text { Sebelu } \\
\text { m }\end{array}$ & Sesudah \\
\hline SP1 & 45.015 & 100.000 & 25 & 90.55 & 92.95 \\
\hline SP2 & 45.020 & 99.995 & 25 & 90.35 & 92.90 \\
\hline SP3 & 45.005 & 100.000 & 25 & 90.75 & 93.32 \\
\hline $\begin{array}{l}\text { Margi } \\
\mathrm{n}\end{array}$ & $\begin{array}{r}45 \pm 0.02 \\
0\end{array}$ & $100 \pm 0.005$ & $25 \pm 0$ & $\begin{array}{r}90 \pm 0.7 \\
5\end{array}$ & $93 \pm 0.32$ \\
\hline Maks & 45.020 & 100.000 & 25 & 90.75 & 93.32 \\
\hline Min & 45.005 & 99.995 & 25 & 90.35 & 92.90 \\
\hline $\begin{array}{l}\text { Rata- } \\
\text { rata }\end{array}$ & 45.013 & $\begin{array}{r}99.9983333 \\
3\end{array}$ & 25 & 90.55 & $\begin{array}{r}93.0566 \\
7\end{array}$ \\
\hline $\begin{array}{l}\text { Devias } \\
\text { i } \\
\text { standar }\end{array}$ & 0.0076 & 0.0029 & 0 & 0.2 & 0.23 \\
\hline
\end{tabular}

Keausan berdasarkan jam operasi

\begin{tabular}{|c|c|c|c|}
\hline & \multicolumn{3}{|c|}{ Keausan internal radial clearance, } \\
& \multicolumn{3}{|c|}{$\mu \mathrm{m}$} \\
\hline Jam & SP1 & SP2 & SP3 \\
\hline 0 & 90.55 & 90.35 & 90.75 \\
\hline 100 & 91.14 & 90.90 & 91.17 \\
\hline 200 & 91.64 & 91.30 & 91.83 \\
\hline 300 & 91.96 & 91.89 & 92.17 \\
\hline 400 & 92.63 & 92.30 & 92.82 \\
\hline 500 & 92.95 & 92.90 & 93.32 \\
\hline
\end{tabular}




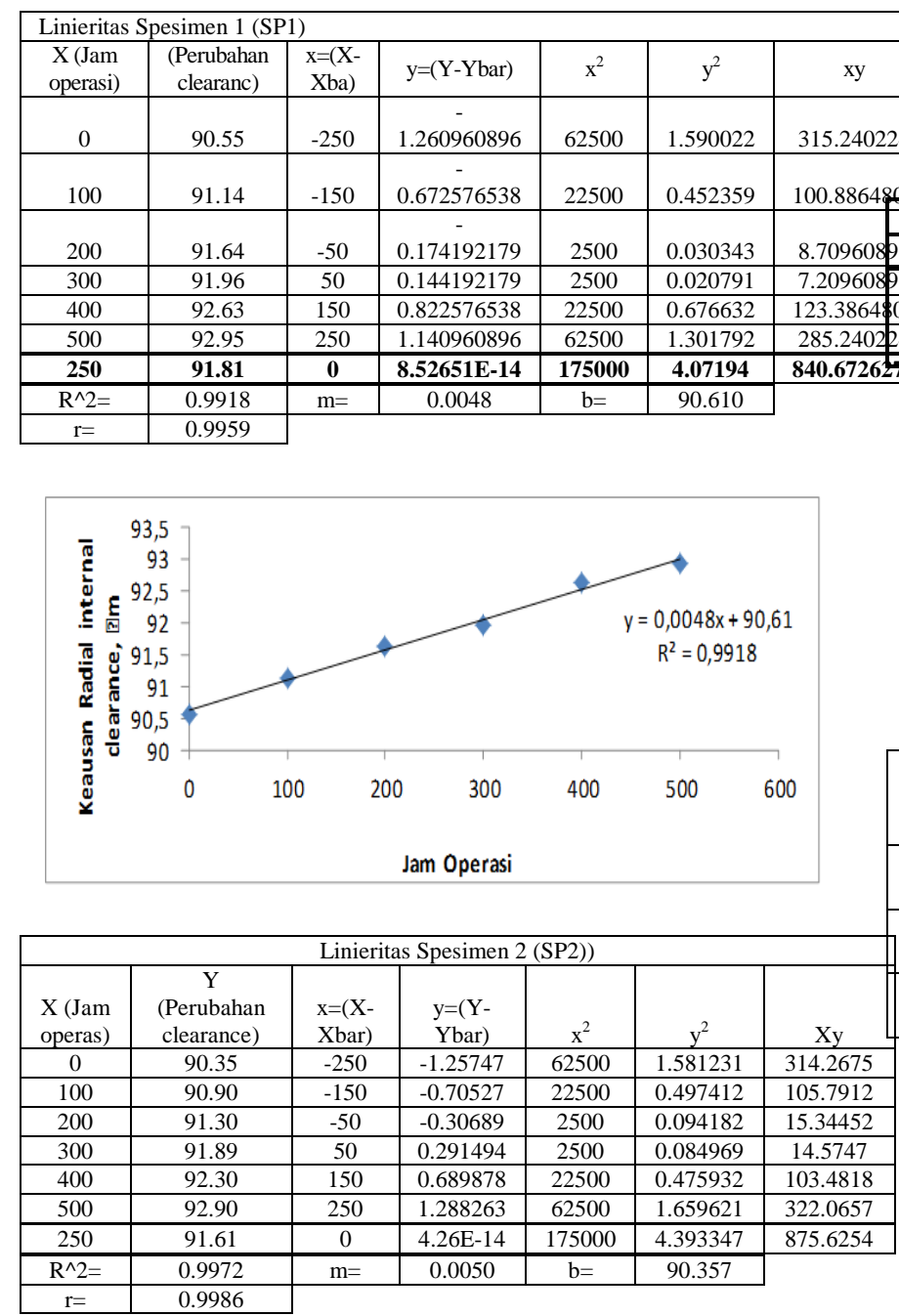

Fungsi linier SP1

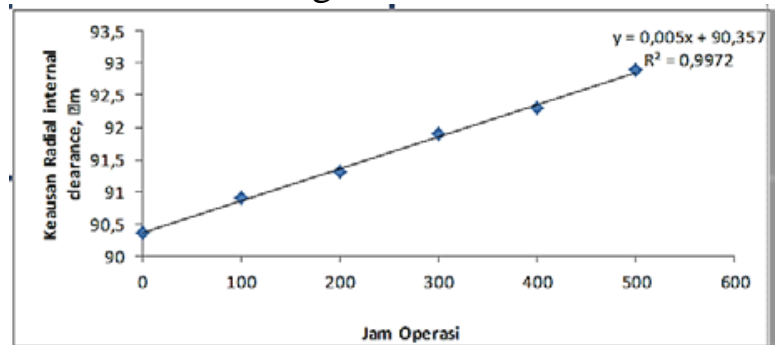

Fungsi linier SP2
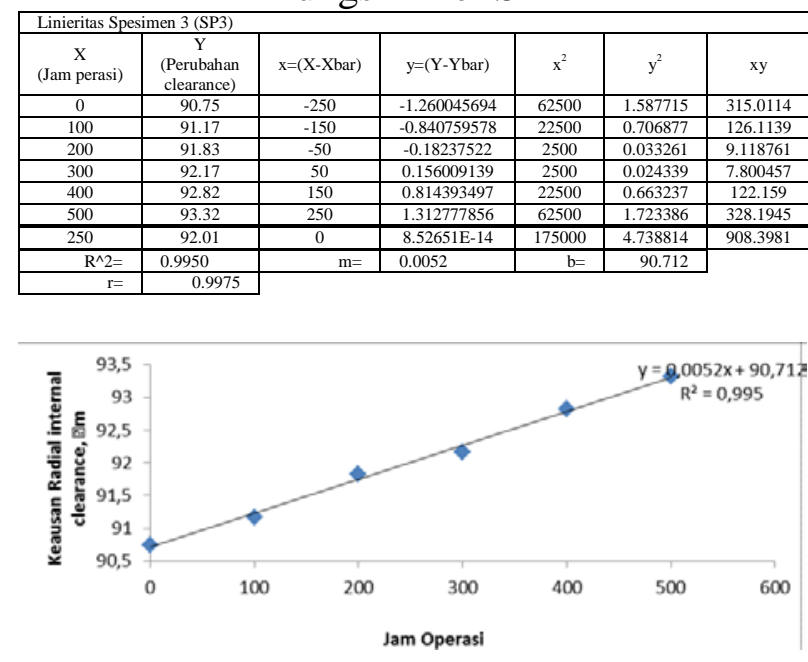

Fungsi linier SP3

Prediksi ambang batas keausan masingmasing specimen

\begin{tabular}{|c|c|c|c|c|c|c|c|c|c|}
\hline & \multicolumn{3}{|c|}{ SP1 } & \multicolumn{3}{c|}{ SP2 } & \multicolumn{3}{|c|}{ SP3 } \\
\hline & $\mathrm{m}$ & $\mathrm{b}$ & $\mathrm{x}$ & $\mathrm{m}$ & $\mathrm{b}$ & $\mathrm{x}$ & $\mathrm{m}$ & $\mathrm{b}$ & $\mathrm{x}$ \\
\hline 0.0 & 90. & 37759 & 0.0 & 90. & 363 & 0.0 & 90. & 349 \\
048 & 610 & .3477 & 050 & 357 & 02.7 & 052 & 712 & 24.5 \\
\hline
\end{tabular}

\begin{tabular}{|c|c|c|}
\hline \multicolumn{3}{|c|}{ Ambang batas operasi, jam } \\
\hline SP1 & SP2 & SP3 \\
\hline 37759 & 36303 & 34925 \\
\hline
\end{tabular}

$\ln ($ Kegagalan) versus $\ln (\ln (1 /(1-$ Mean Ranks)))

\begin{tabular}{|c|c|c|c|c|c|}
\hline $\begin{array}{c}\text { Prediksi } \\
\text { kegagalan } \\
\text { (jam) }\end{array}$ & $\begin{array}{c}\text { Ran } \\
\mathrm{k}\end{array}$ & $\begin{array}{c}\text { Median } \\
\text { Ranks } \\
(\mathrm{MR})\end{array}$ & $1 /(1-\mathrm{MR})$ & $\begin{array}{c}\ln (\ln (1 /(1- \\
\mathrm{MR})))\end{array}$ & $\begin{array}{c}\ln (\text { Kega } \\
\text { galan })\end{array}$ \\
\hline 34925 & 1 & $\begin{array}{c}0.20588 \\
2353\end{array}$ & $\begin{array}{c}1.25925925 \\
9\end{array}$ & -1.467401781 & $\begin{array}{c}10.4609 \\
5818\end{array}$ \\
\hline 36303 & 2 & 0.5 & 2 & -0.366512921 & $\begin{array}{c}10.4996 \\
5566\end{array}$ \\
\hline 37759 & 3 & $\begin{array}{c}0.79411 \\
7647\end{array}$ & $\begin{array}{c}4.85714285 \\
7\end{array}$ & 0.457709854 & $\begin{array}{c}10.5389 \\
7914\end{array}$ \\
\hline
\end{tabular}

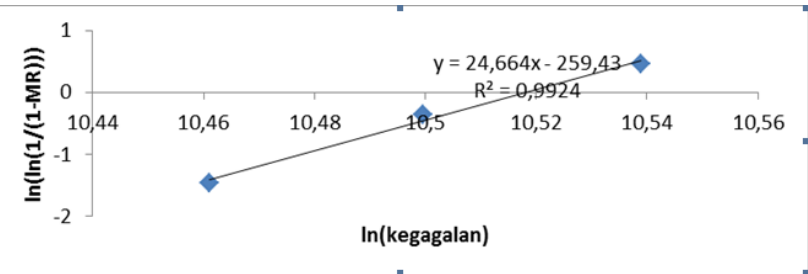

Fungsi linier Ambang batas keausan

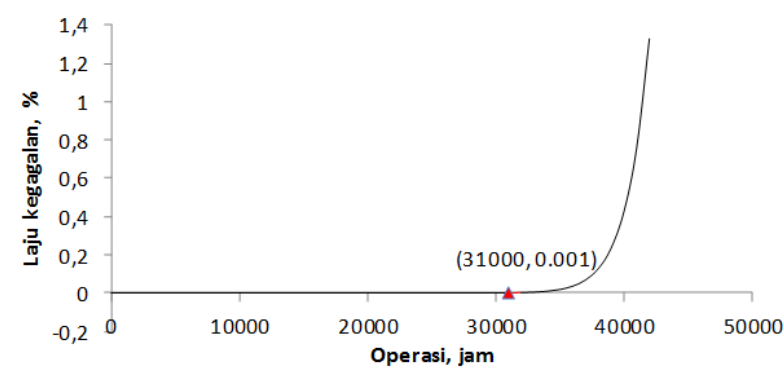

Kurva Jam operasi vs Laju kegagalan

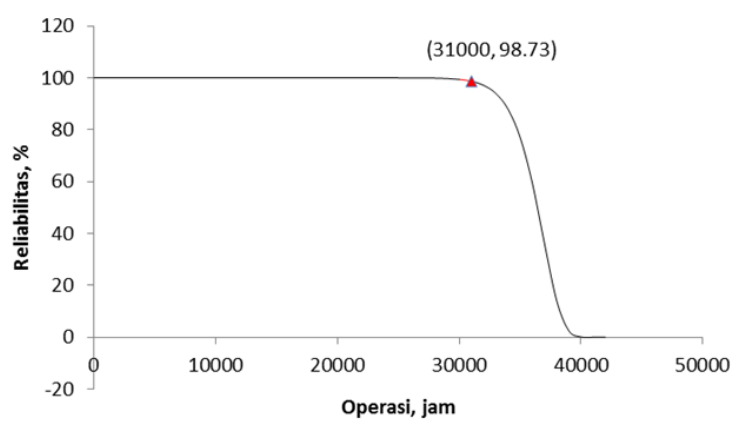

Kurva jam operasi vs Keandalan 


\section{SIMPULAN}

- Umur ball bearing dipengaruhi oleh tiga parameter utama yaitu; beban, putaran dan temperature. Untuk diesel engine stationer, dua parameter awal dapat terjaga namun temperatur operasi melewati batas ambang sangat berperan dalam menentukan penurunan umur bantalan karena berhubungan langsung dengan perubahan clearance ketika dioperasikan. Sehingga untuk bantalan yang diteliti dengan temperature operasi maksimum $100^{\circ} \mathrm{C}$ memerlukan initial clearance 90 mikron dengan batas ambang keausan (final clearance) 272 mikron.

- Penurunan reliabilitas 99.99\% dan peningkatan laju kegagalan $3,5 \times 10^{-11} \%$ radial ball bearing sebagai fungsi jam operasi dimana deteorisasi mulai terjadi yaitu pada jam opersi 15000 jam, dan berikutnya laju kegagalan terus meningkat seiring dengan akumulasi dari keasan yang terjadi. Pada reliabilitas $98.73 \%$ atau laju kegagalan 0.001\% merupakan awal akumulasi peningkatan laju kegagalan yaitu terjadi pada 31000 jam operasi. Untuk mempertahanakan umur andal dan antisipasi akumulasi laju kegagalan bantalan maka penggantian sebaiknya dilakukan pada jam operasi 31000 jam. Walaupun penggantian bantalan pada operasi 31000 jam jauh dibawah umur empirik pada 37374 jam, namun dapat diterima oleh karena perhitungan umur empirik mengacu pada sepuluh persen populasi bearing yang tidak akan mencapai batas umur yang ditentukan disamping itu umur empirik mengacu pada asumsi bahwa komponen lainnya beroperasi normal.

\section{DAFTAR PUSTAKA}

Arismunandar. W, 1998, "Penggerak Mula Motor Bakar Torak”, Penerbit ITB;Bandung

Khovack. M, 1968, "Motor Vehicle Engines” International Edition, Mir Publishers, Moscow.

Maleev, V, L, 1945, “ Internal - Combustion Engine “, Mc Graw Hill Book, Co; New York.

Maintenance replacement and Reliability ; Theory and Applications Andrew K.S Jardine and Albert H.C Tsang . Taylor \& Francis

Petrovsky. N, 1968, "Marine Internal Combustion Engines", Interntional Edition, Mir Publishers; Moscow,
PT SKF Indonesia, 2002, “ Training Pengetahuan Bearing “, PT SKF Indonesia; Jakarta.

Shigley, Joseph, E, 1999, “ Perencanaan Teknik Mesin “, Jilid 1, Penerbit Erlangga; Jakarta.

Shigley, Joseph, E, 1999, “ Perencanaan Teknik Mesin “, Jilid 2, Penerbit Erlangga; Jakarta.

Sularso dan Suga, kyokatsu, 1983, “ Dasar - dasar Perencanaan dan Pemilihan Elemen Mesin, Pradnyaparamita; Jakarta

Reinholtz,Charles, Kinematics and Dynamics of Machinery, Prentice Hall, 1990

Holowenko, A.R, Kinematics and Dynamics of Machinery, Erlangga, 1993

Wilson, Charles, Kinematics and Dynamics oh Machinery, Harper \& Row, New York, 1983

David F. Griffiths, An Introduction to Matlab, The University Dundee, Stockholm, Sweden, 2001

Mark's Standard Handbook for Mechanical Engineer, $9^{\text {th }}$ ed.

Paul K. Yin, Numerical methods on Spreadsheet for Machinnery Design Project, International journal Engineering Ed Vol. 13, No. 6, p. 412-416, Great Britania, 1997

Rajput, R.K. Thermal Engineering, Laxmi Publication (P) LTD, New Delhi, 2003 http://emissary.prenhall.com/esource 